\title{
The importance of millet production in regional production, with special emphasis on climate change
}

\author{
${ }^{1}$ Emese Seres - ${ }^{2}$ Mihály Sárvári \\ ${ }^{1}$ Fitt Agro Kft., Mátészalka \\ ${ }^{2}$ University of Debrecen, Faculty of Agricultural and Food Science and Environmental Management, \\ Institute of Crop Science, Debrecen \\ seres.emese@gmail.com
}

SUMMARY

\begin{abstract}
Regional production is a traditional production structure developed adjusting to the geographical, climatic, biological and soil conditions in given production regions, a certain territorial specification of agricultural production, and a type of farming that best fits the natural conditions and takes the biological needs of plant and animal species into account as fully as possible. The most probable element of risk in plant production is the changeable, extreme weather. That is the reason why the specific characteristics of the place of production and the characteristics of regional production should be considered to a greater extent. The establishment of the range of varieties appropriate for the place of production is the key issue in regional production. One of our historically grown cereal plants that perfectly fits regional production is millet. Due to its short growing season, favourable reproduction ratio and the fact that it is relatively undemanding, it used to be grown in larger quantities in the middle ages. Its good nutritional values made it an important food item, but over time, as a result of industrialisation and technological progress; it has been eclipsed by other cereal crops. In our country it is mainly used to cook porridge, but it is also used in the form of flour and as a base material in the spirit drinks sector. In the recent decades, millet has been applied only in a small area, mostly as a secondary crop in areas that dried out from drainage water in late spring, or as a replacement of extinct sowings due to its late sowing time. Water will be the most significant factor for the future of agriculture, especially considering climate change.

My examinations took place in the area of the Institutes for Agricultural Research and Educational Farm of University of Debrecen, in the Research Institute of Nyíregyháza, in a small-plot experiment with four replications in 2016.
\end{abstract}

Keywords: millet, sowing date, regional production, climate change

\section{INTRODUCTION}

The world's food supply can be significantly improved with the further use of millet, as it is cheaper than traditional proteins. The role/significance of millet in human nutrition increased again in Europe and Hungary. In Hungary, millet is mainly known as a crop for pap production purposes, while also flour and distilling industry materials are produced from its yield. Currently, millet is produced on a small area, mainly in dual production to replenish perished crop areas or to utilize areas with groundwater infiltration which dry up late.

The significance of millet is further increased by climate change, as it needs warm weather to grow. Furthermore, millet could increase the diversity of field crop species. Based on the inflorescence of the produced millet, three variants are known as follows (Schermann 1967, Mansfeld 1986, Lazányi 1997):

- millet with diverging panicle (Panicum miliaceum var. effusum.)

- millet with contracted panicle (Panicum miliaceum var. contractum)

- millet with compact upright panicle (Panicum miliaceum var. compactum).

Due to its intrinsic nature of regional development, the agroecological conditions of the given region need to be taken into account. Within and compared against the area of Hungary, there are significant differences in the agroecological characteristics of different regions. Ángyán and Menyhért (1988) summarized the end values with $95 \%$ frequency of some elements of the two most important group of agroecological factors (climate, soil) (Table 1).

Based on the characteristics of given regions, Hungary can split into agroecological areas. Those areas need to be divided in relatively smaller units due to the diversity of the areas of the country - to properly reflect the diverse climatic, soil, hydrological and surface characteristics of the country as well as the agricultural production and its structure and results. To mark the agroecological areas, the natural and geographical mesoregions, that have already been developed and improved (Stefanovits 1952), proved to be the most suitable. The natural and geographical mesoregions can also be considered as agroecological areas. These areas consist of smaller regions, ecological units within which the development of the region, due to the interaction between the prevailing regional ecological factors, the characteristics of the place of production and the regional potential is similar (Bocz 1996).

There are two methods of adjusting the plant/sowing structure to the given ecological conditions:

- choosing plant species and varieties, the agroecological requirements of which are close to the characteristics of the place of production,

- improvement of varieties which have agroecological requirements that comply with the natural conditions of the given area. 
The end values with $95 \%$ frequency of some agroecological characteristics in Hungary (1901-1980)

\begin{tabular}{|c|c|c|c|}
\hline \multirow{2}{*}{ Characteristic } & \multirow{2}{*}{ Measurement unit } & \multicolumn{2}{|c|}{ Limit value $\mathrm{P}=95 \%$} \\
\hline & & Minimum & Maximum \\
\hline Duration of sunshine (IV-IX) & hour & 1300 & 1500 \\
\hline Air temperature (IV-IX) & ${ }^{\circ} \mathrm{C}$ & 16 & 18 \\
\hline Accumulated temperature (IV-IX) & ${ }^{\circ} \mathrm{C}$ & 2910 & 3260 \\
\hline Precipitation (X-III) & $\mathrm{mm}$ & 240 & 320 \\
\hline Precipitation (IV-IX) & $\mathrm{mm}$ & 310 & 460 \\
\hline Precipitation (X-IX) & $\mathrm{mm}$ & 550 & 780 \\
\hline Liquid limit $\left(\mathrm{K}_{\mathrm{A}}\right)$ & - & 25 & 60 \\
\hline $\mathrm{pH}$ & - & 3.9 & 7.9 \\
\hline Humus content & $\%$ & 0.4 & 4.3 \\
\hline $\mathrm{P}_{2} \mathrm{O}_{5}$ & $\mathrm{mg} \mathrm{kg}^{-1}$ & 30 & 380 \\
\hline $\mathrm{K}_{2} \mathrm{O}$ & $\mathrm{mg} \mathrm{kg}^{-1}$ & 60 & 480 \\
\hline
\end{tabular}

Source: Ángyán and Menyhért (1988)

Accordingly, it is worth reviewing our ancient, indigenous plant species and varieties or the ones that started to grow here in old times. It is also expedient to rethink our improvement and variety qualification programmes, principles and objectives questioning that how much they are suitable to establish the biological bases of adapting farming systems. In the ecological adaptation, knowing and applying those crops that have best adjusted to their environment, as a result of their adapting development through centuries and thousands of years, can again be determining. With this approach, millet can be the perspective plant of the region of Nyírség.

Nyírség is a mesoregion in the north-eastern part of the Great Hungarian Plain. On the soil of the Northern Great Plain with unfavourable characteristics (soils with heavy mechanical composition along Central Tisza) production potentials are limited, there are few plant species there that can be grown successfully and productively. On the other hand, the production is of higher risk than in regions with better potentials. Unfavourable characteristics also determine a smaller range of plant species that can be produced there as well as the method of production and the expectable results. Hungary's production structure, and that of the Northern Great Plain, is focused on cereals, and within that only a few species have a determining role. Similar to other parts of the country, maize and wheat are typical, which, due to their ecological requirements, can be grown with modest results in this region. However, plant species that fit in the region have low area ratio (Gondola 2010).

In the Middle Ages, millet was a porridge plant with strategical importance, but when maize appeared and had spread, millet was pushed to background. It can be said that since the second half of the $19^{\text {th }}$ century, its production had been stopped in Europe. In the middle of the $18^{\text {th }}$ century, in Hungary, millet was grown on large areas (Wellmann et al. 1963).

Millet has extreme production results, as experts also said: ,In some years the amounts of the crop are so large that you cannot believe your eyes. In some other cruel years, the crop is that much less, thus it is not a reliable sowing" (Angyalffy 1824).

In global terms, millet has the largest production area and amounts of crop in Africa and Asia. Average yields are the lowest in Africa and the highest in America. In terms of the given years, there are significant differences between yield results (Figure 1).

The biggest millet producer of the world is India, and in order, it is followed by Niger, Nigeria and China. India produces 12.09 million tonnes, which is more than $42 \%$ of the world's millet production.

Until the last decade of the $20^{\text {th }}$ century, millet was applied as a secondary sowing and to replace extinct autumn sowings. Today in Hungary the sowing area and average yield of millet is growing again, which is stimulated by the good potential in its export (Figure $2)$. In Hungary, improvement and maintenance of varieties of millet is carried out in many places (e.g. Research Institution of Nyíregyháza and Karcag, University of Debrecen etc).

\section{MATERIAL AND METHOD}

The experiment for the sowing time, plant number and fertilization of millet took place in Institutes for Agricultural Research and Educational Farm of University of Debrecen, in the Research Institute of Nyíregyháza, in 2016. The purpose of my investigation was to express the effect of the sowing time, the nutrient supply and the growing area in numbers in terms of the yield, the protein content and the milling yield.

In March 2016, there was more precipitation than the average. Among the months of spring, April was dryer than the average, and in June the total amount of precipitation was more than $120 \mathrm{~mm}$. Overall, the temperature in the growing season was higher than the average by $1.2{ }^{\circ} \mathrm{C}$, while the amount of precipitation in the vegetation period was the same as the average of many years (Figure 3), with very hectic distribution. 
Figure 1: The sowing area and average yield of millet in the world

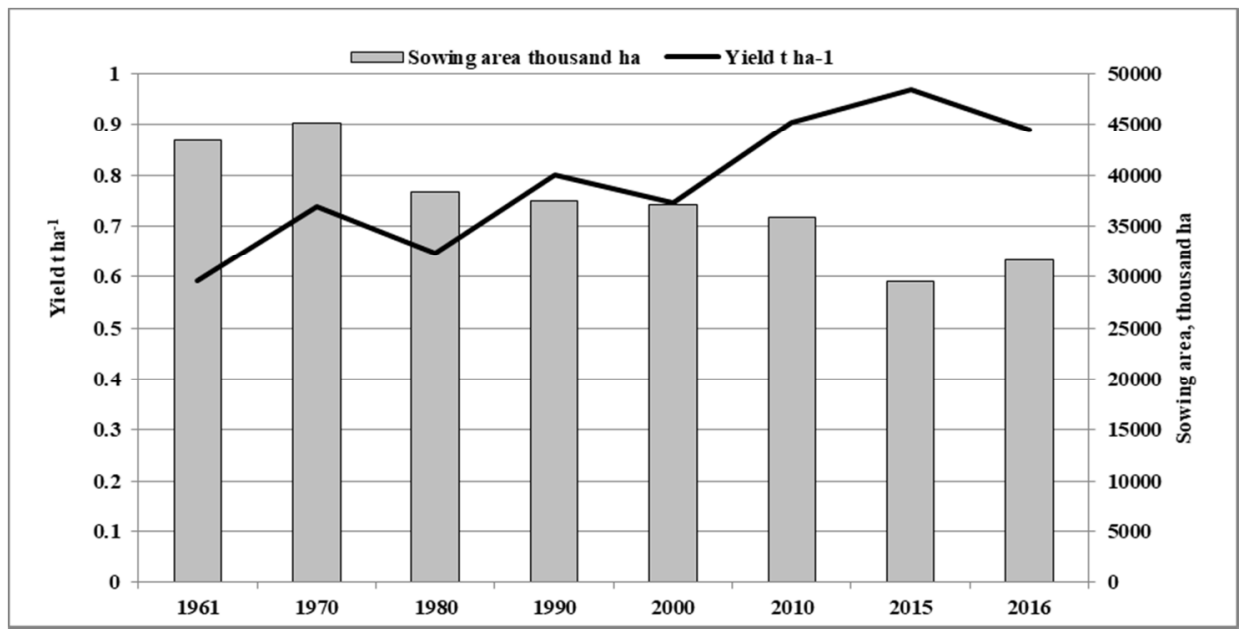

Source: FAO data

Figure 2: Sowing area and average yield of millet in Hungary

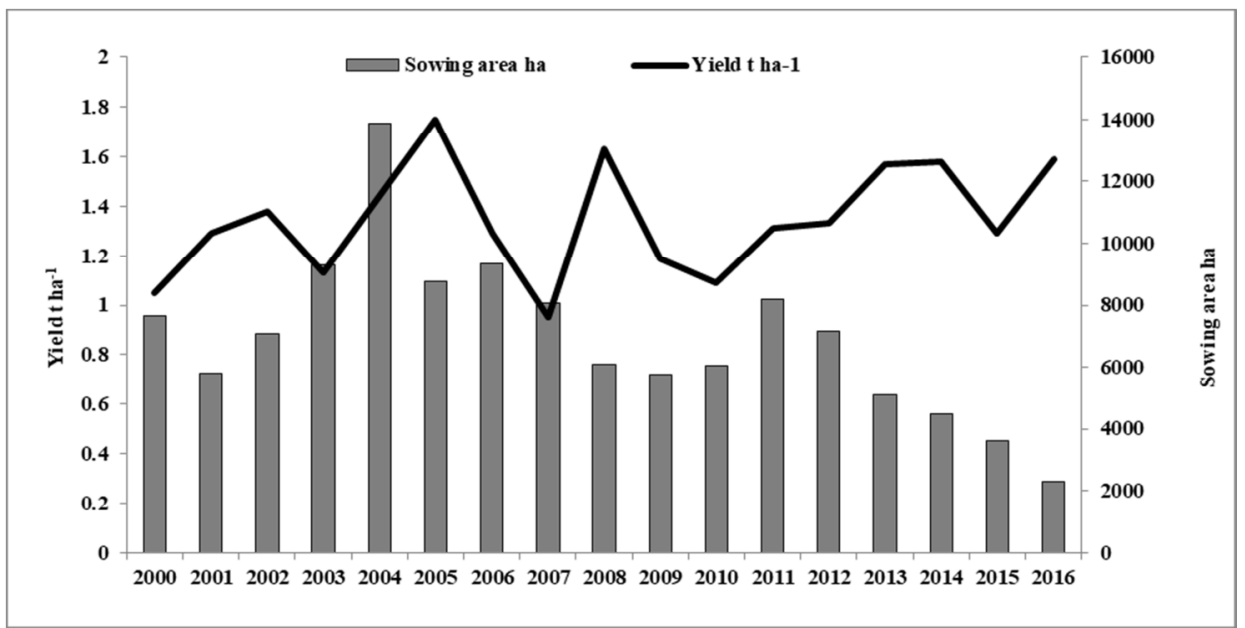

Source: KSH data

Figure 3: The change of the temperature and precipitation (Nyíregyháza, 2016)

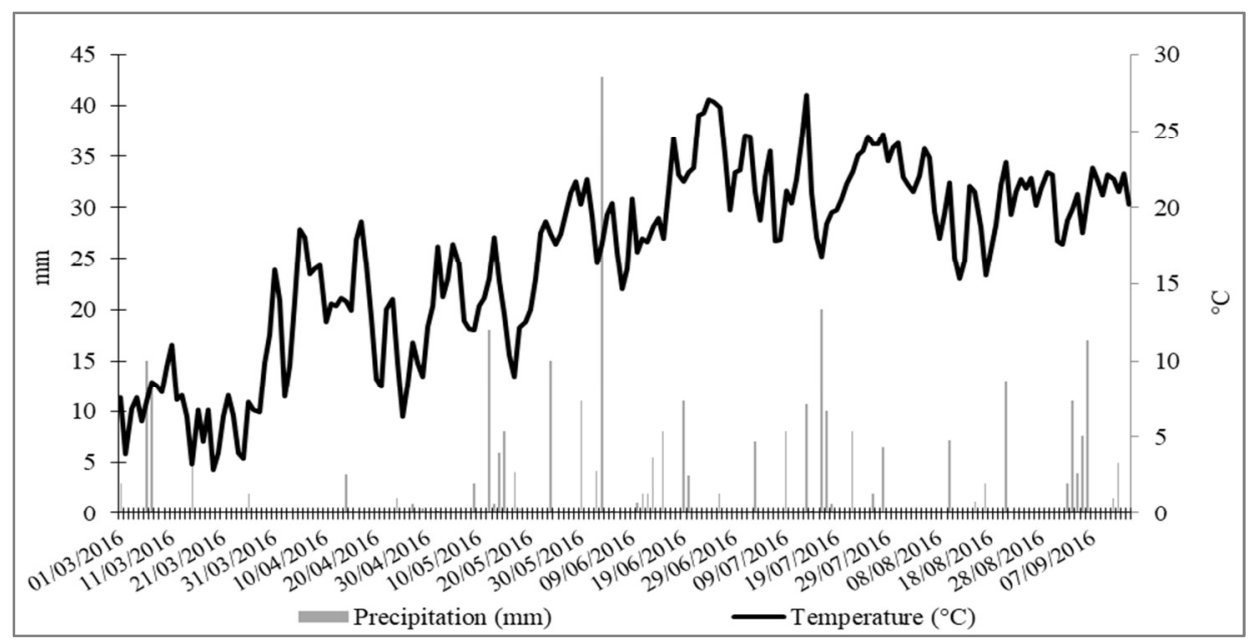


The soil of the experimental area has a low liquid limit $\left(\mathrm{K}_{\mathrm{A}}=28\right)$, acidic $\mathrm{pH}$ and low water holding capacity. Because of its unfavourable mechanical combination, field leaching is intensive, the macro- and micronutrient content of the soil is low. Its $\mathrm{pH}$ is acidic, physically it is sand. Its water and nutrient management is better than that of quicksand, its humus content is approximately $1 \%$.

This soil is disposed to deflation, its water holding capacity is low. These parameters refer to the fact that the test area has extensive values, which provide acceptable circumstances for millet, considering its excellent adaptability (Table 2).

Table 2

Soil properties of the area taking part in maintenance of millet varieties (Nyíregyháza, 2015)

\begin{tabular}{|c|c|c|}
\hline $\mathrm{pH}(\mathrm{KCl})$ & & 5.6 \\
\hline Liquid limit & $\left(\mathrm{K}_{\mathrm{A}}\right)$ & 27 \\
\hline Water-soluble salt & $\%(\mathrm{~m} / \mathrm{m})$ & $<0.02$ \\
\hline Total carbonate content & expressed in $\mathrm{CaCO}_{3}$ & N.N. \\
\hline Humus\% & $\%(\mathrm{~m} / \mathrm{m})$ & 1.19 \\
\hline Sulphate & & 8.3 \\
\hline $\mathrm{N}\left(\mathrm{NO}_{2}+\mathrm{NO}_{3}\right)$ & $\mathrm{mg} \mathrm{kg}^{-1}$ & 4.96 \\
\hline $\mathrm{P}_{2} \mathrm{O}_{5}$ & $\mathrm{mg} \mathrm{kg}^{-1}$ & 150 \\
\hline $\mathrm{K}_{2} \mathrm{O}$ & $\mathrm{mg} \mathrm{kg}^{-1}$ & 210 \\
\hline $\mathrm{Mg}$ & $\mathrm{mg} \mathrm{kg}^{-1}$ & 62.4 \\
\hline $\mathrm{Na}$ & $\mathrm{mg} \mathrm{kg}^{-1}$ & 7.9 \\
\hline $\mathrm{Zn}$ & $\mathrm{mg} \mathrm{kg}^{-1}$ & 3.43 \\
\hline $\mathrm{Cu}$ & $\mathrm{mg} \mathrm{kg}^{-1}$ & 9.59 \\
\hline $\mathrm{Mn}$ & $\mathrm{mg} \mathrm{kg}^{-1}$ & 117 \\
\hline
\end{tabular}

The plots of the small-plot experiment were arranged in randomized blocks. The size of each block is $2 \times 10 \mathrm{~m}$, harvesting took place on an area of $1.5 \times 10$ $\mathrm{m}$. In the experiment, in the production of millet, elements of large scale production technology were applied. These agrotechnical elements were:

- fertilization (B):

b1 - control $\left(\mathrm{N}_{0} \mathrm{P}_{2} \mathrm{O}_{5} 0 \mathrm{~K}_{2} \mathrm{O} 0\right)$

b2 - $\mathrm{N}_{40} \mathrm{P}_{2} \mathrm{O}_{5} 48 \mathrm{~K}_{2} \mathrm{O} 48$,

b3 $-\mathrm{N}_{80} \mathrm{P}_{2} \mathrm{O}_{5} 72 \mathrm{~K}_{2} \mathrm{O} 72$, b4 - $\mathrm{N}_{120} \mathrm{P}_{2} \mathrm{O}_{5} 96 \mathrm{~K}_{2} \mathrm{O} 96$,

- sowing date $(\mathrm{A})$ :

a1 - 20/05/2016.

a2 $-06 / 06 / 2016$.

a3 - 25/05/2016,

- growing area $(\mathrm{C})$ :

$\mathrm{c} 1-12 \mathrm{~cm}$ between the rows,

$\mathrm{c} 2-24 \mathrm{~cm}$ between the rows,

$\mathrm{c} 3-36 \mathrm{~cm}$ between the rows.

Amounts of nutrients were spread in NPK 8:24:24 and MAS 27:0:0 fertilizers. Varieties applied in the experiment: Lovászpatonai, Rumenka, Biserka and Maxi.

Harvesting was performed with Zürn 130 SE plot combine harvester. Statistical evaluation of the gained results was carried out with SPSS for Windows ${ }^{\circledR}$ programme, with two-way analysis of variance and Tukey's test.

\section{RESULTS AND DISCUSSION}

It can be concluded that the correlation between sowing time and yield significantly varied also between the different varieties. With the 1st sowing date (20 May), the yield of varieties changed between 1.65-2.65 $\mathrm{t} \mathrm{ha}^{-1}$. With the $1^{\text {st }}$ sowing date, the highest yield was produced by variety Maxi.

The examined varieties had different responses to the change in the distance between the rows. Variety Rumenka, even if its productivity is lower, produced nearly the same yields on the three different growing areas (distances between the rows), very similar to variety Maxi. A close correlation can be detected between the variety, the growing area and the effect of the crop year, which is a reason why research should be continued. Variety Maxi confirms not only the importance of the agricultural properties but that of the biological bases, since it produced a higher yield than that of all the other varieties, even with different agrotechnical factors.

In this multifactorial experiment the harvested amounts of crop changed between 1.46-2.94 $\mathrm{t} \mathrm{ha}^{-1}$ (Figure 4-5).

Figure 4: The effect of the sowing time on the different varieties of millet, on acidic soil (Nyíregyháza, 2016)

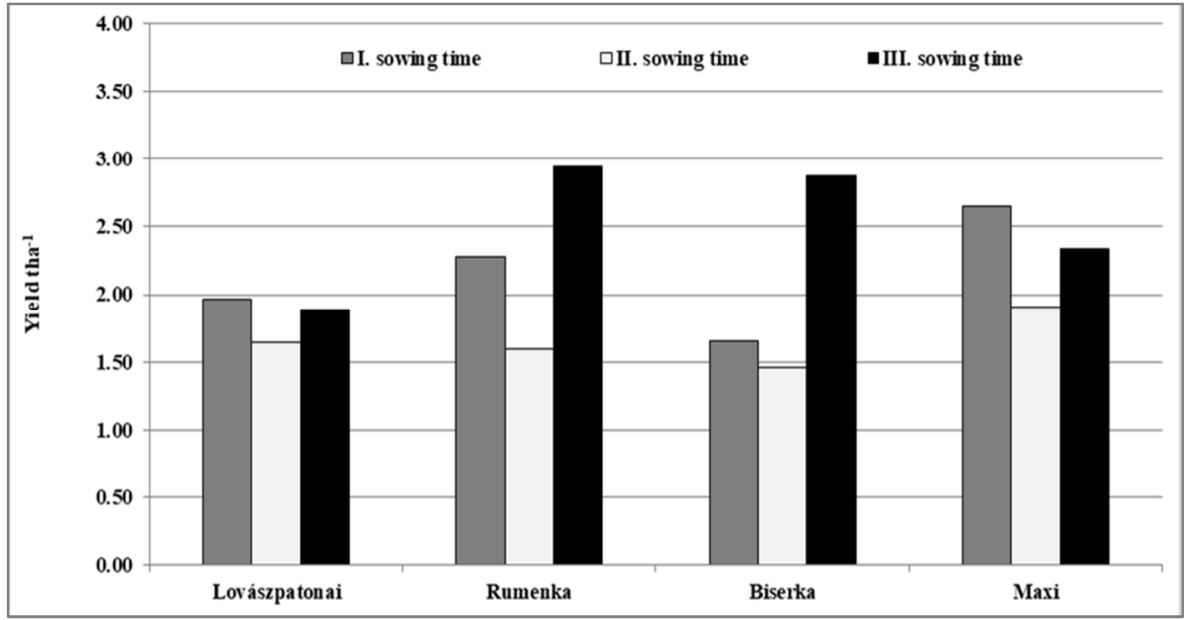


Figure 5: The effect of the growing area on the different varieties of millet, on acidic soil (Nyíregyháza, 2016)

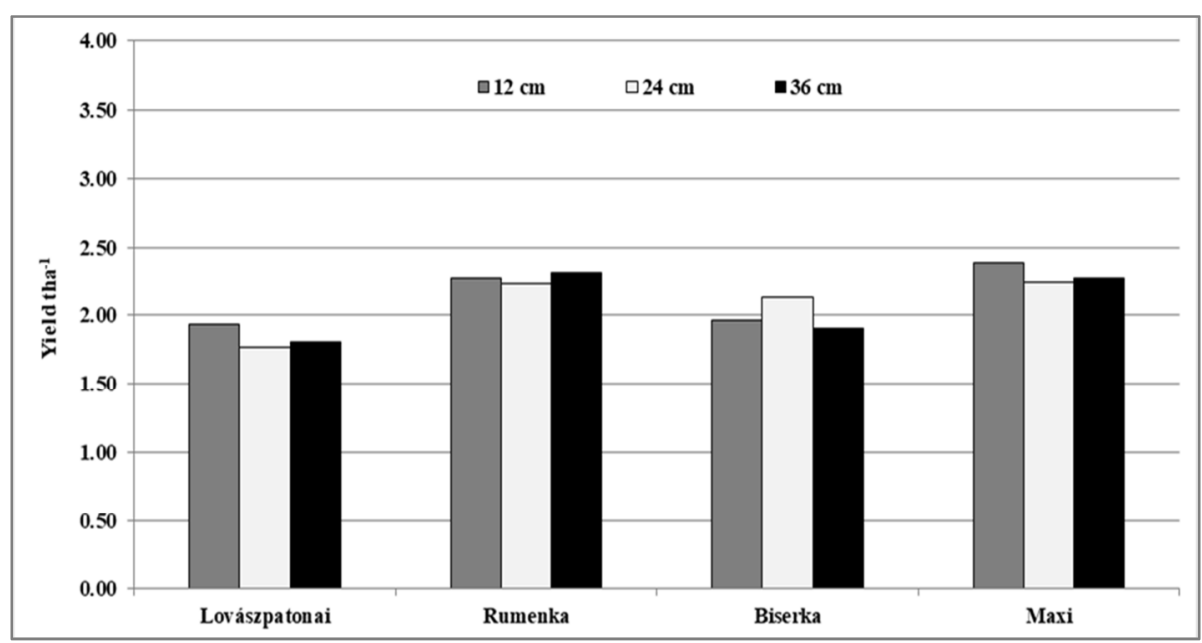

Between the different levels of fertilization, in the average of the treatments, the detectable effect of nutrient supply was not that obvious. The efficiency of fertilization, among the other analysed factors, the sowing time influenced at a great extent. In terms of the growing area, there was no significant difference between the effects of the different row distances (Figure 6).

Figure 6: The effect of the nutrient supply and the genotype on the yield of millet (Nyíregyháza, 2016)

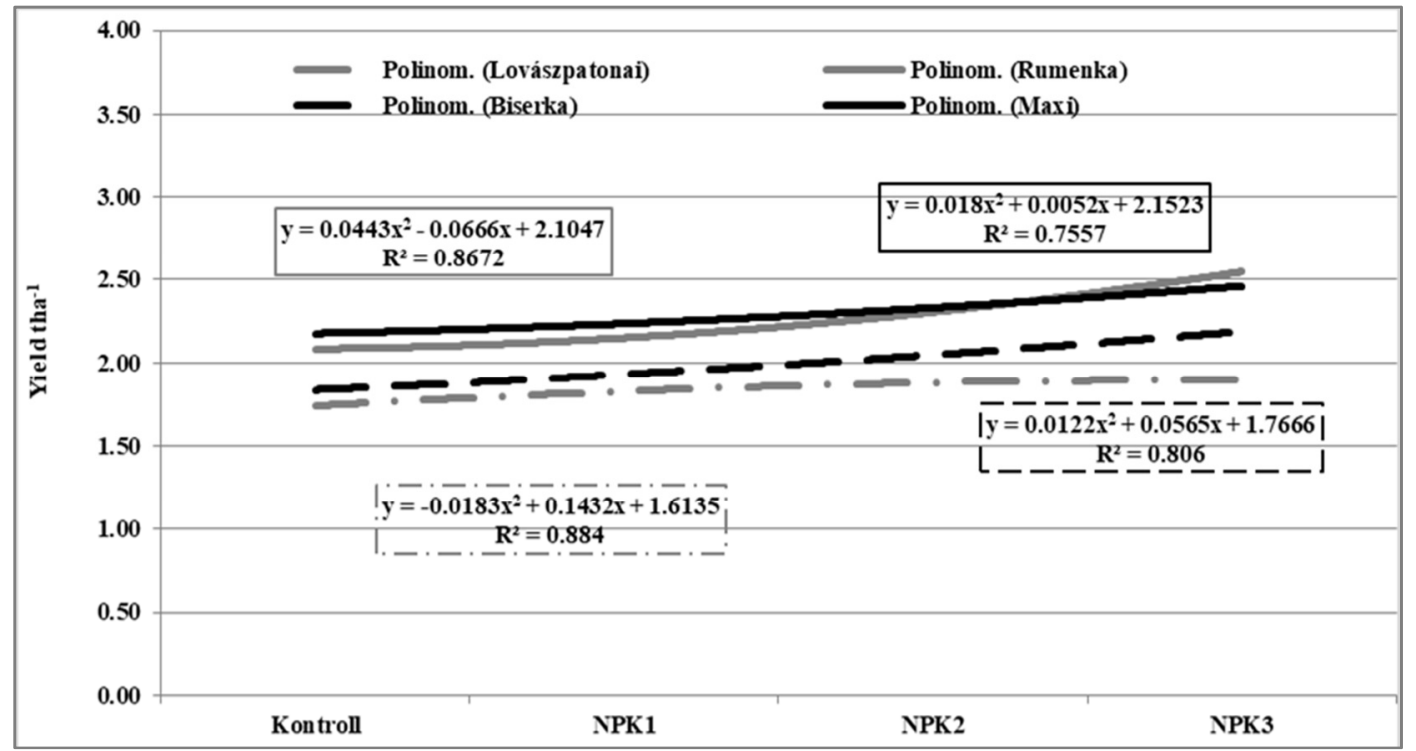

\section{CONCLUSIONS}

The examination of millet's production technological elements is important also because, due its good adaptability, it is considered as one from the group of undemanding plants. This characteristic makes it suitable for being grown as a secondary sowing. However, with the application of late sowing dates, it has to be taken into account that the crop year can significantly modify the response of the plant to the production technology inputs.
Overall, I could conclude that millet can well applied both as a primary or secondary sowing, also in extremely dry areas with unfavourable distribution of precipitation, and on soils of lower quality, due to its good water utilization capability, it is relatively undemanding, and it has a short growing season. Consequently, it can be grown with good results also in other regions with similar agroecological characteristics.

I believe that there is a great future potential in the regional production and variety improvement of millet, as due to its excellent nutritional values, it can 
be a plant of key importance not only in the production of traditional, but modern functional food items and the production of healthy local food ingredients as well.

Based on the results of our experiment, we can state that millet is a plant with wide interval of optimum sowing dates, with the fact that the extremely late sowing dates significantly increases the risk of production.

Millet is an aggressive plant, it very well utilizes the nutrients in the soil. In 2016 the maximum yield was produced with the a 3 sowing date, which can also be correlated with the distribution of precipitation.

\section{REFERENCES}

Angyalffy M. (1824): Mezei gazdák' barátja I-II. Trattner. Pesth. Ángyán J.-Menyhért Z. (1988): Integrált, alkalmazkodó növénytermesztés (Ésszerü környezetgazdálkodás). Közgazdasági és Jogi Könyvkiadó. Budapest. 163.

Bocz E. (1996): Magyarország klíma- és talajadottságai. Szántóföldi növénytermesztés. Mezőgazda Kiadó. Budapest. 44-69.

Gondola I. (2010): Az alternatív növények szerepe az Észak-alföldi Régióban. DE AGTC KIT Nyíregyházi Kutatóintézet. Nyíregyháza. 5-7.

Lazányi J. (1997): Kölestermesztés. [In. Fazekas M. (szerk.) Amit a cirok és madáreleség félékröl tudni kell.] FM Kiadvány. Budapest. 70-79.
Mansfeld, R. (1986): Verzeichnis landwirtschaftlicher und gärtnerischer Kulturplanzen (ohne Zierpflanzen) I-IV. Berlin, Heidelberg, New York, Tokyo. 1998.

Stefanovits P. (1952): Talajtájaink és gyakorlati jelentőségük. MTA Agrártud. Oszt. Közl. 302-313.

Schermann Sz. (1967): Magismeret I. Akadémiai Kiadó. Budapest. 861.

Wellmann I.-Mándy Gy.-Mesch J. (1963): Száznegyven esztendős búzakalász-lelet. Agrártört. Szeml. 4: 1-43. 